\title{
In vitro assessment of nutritive value of date palm by-products as feed for ruminants
}

\author{
Souhil Boufennara ${ }^{1,2 *}$, Lyas Bouazza', Antonio de Vega $^{2}$, Manuel Fondevila², Zahia Amanzougarene ${ }^{2}$, \\ Secundino Lopez ${ }^{3}$ \\ ${ }^{1}$ Département de Biologie Moléculaire et Cellulaire, Faculté des Sciences de la Nature et de la vie, Université Abbès Laghrour de Khenchela, \\ 40000 Khenchela, Algeria, ${ }^{2}$ Departamento de Producción Animal y Ciencia de los Alimentos, Instituto Agroalimentario de Aragón-IA2- \\ (Universidad de Zaragoza-CITA), Miguel Servet 177, 50013, Zaragoza, Spain, ${ }^{3}$ Instituto de Ganadería de Montaña (IGM) CSIC-Universidad \\ de León, Departamento de Producción Animal, Universidad de Léon, 24007 León, Spain
}

\section{A B S TR A C T}

\begin{abstract}
Date-palm leaves, pedicels, date-pits and waste dates are date-palm by-products (DPBP), routinely used as a feed resource by oasis farmers. This work aims to assess in vitro the chemical composition and nutritional value of these DPBP, including waste dates from three varieties (Bouarus, Harchaya and Kentichi). Vetch-oat hay was used as a reference feed material. Palm leaves showed the highest NDF, ADF, lignin and crude protein contents $\left(609,435,84,64 \mathrm{~g} \mathrm{~kg}^{-1} \mathrm{DM}\right.$, respectively). Cumulative gas production at $144 \mathrm{~h}$ of incubation was greatest for Kentichi dates ( $\left.330 \mathrm{~mL} \mathrm{~g}^{-1} \mathrm{DM}\right)$ and lowest for date-pits (69 mL g-1DM). Regardless of the variety, waste dates showed the highest $D M$ effective ruminal degradability $\left(E D=0.48-0.49\right.$; estimated for a passage rate of $0.03 \mathrm{~h}^{-1}$ ) and organic matter digestibility (OMD), whereas date-pits seemed to be a poorly degradable material, with an ED coefficient of $0.09 \mathrm{~g} \mathrm{~g}^{-1}$ DM. The lowest total VFA production from ruminal fermentation was with date-pits and the highest with waste dates of the Bouarus variety. These results suggest that waste dates, albeit their low protein content, should be considered highly digestible with energy concentrations as high as that of vetch-oat hay. Palm leaves and pedicels can be considered as highly fibrous emergency roughages for low-producing animals. When DPBP are used as feedstuffs, protein supplements will be necessary to balance the ruminant diets.
\end{abstract}

Keywords: By products; Chemical composition; In vitro fermentation; Nutritive value; Rumen

\section{INTRODUCTION}

Animal feeding represents one of the highest production costs in livestock farming, especially in arid regions (e.g., Algeria). Production of food for humans and feed for animals is constrained by the shortage of water that limits the utilization of arable land (Osman et al., 2005). The production of forages decreases severely during the dry season, extended in these areas for 6-7 months (from May to October). Ruminants farmed in these regions may be handicapped to cover their nutritional requirements with only natural vegetation, if this is not supplemented with an additional feed, with the result of a reduced performance. Under these conditions, the use of date palm by-products (DPBP) in animal diets could counteract in part the shortage of animal feed resources and subsequently increase milk and meat production.
The date palm is a hardy monocot tree acclimated to arid and desert environments, with a hot and dry climate. This tree, which constitutes the backbone of the oasis agriculture, is an important source of food for the Saharan population and feed for their livestock and offers a wide range of agricultural products (fiber, building material) and benefits (shade) traditionally used for domestic purposes. Waste pulp, discarded fruits and seeds (pits or stones) are the three major byproducts derived from the date fruit processing. Fruits of inferior quality or low-grade that are not intended for human consumption (discarded) may be used as feed, and in the current study will be referred to as waste dates. Palm leaves and pedicels are obtained during the fruit harvesting. DPBP have been used historically in animal nutrition by local farmers in a traditional way (Chehma and Longuo, 2004) and can be a significant source of feed (El Hag, 1995). Dates are rich in carbohydrates

*Corresponding author:

Souhil Boufennara, Département de Biologie Moléculaire et Cellulaire, Faculté des Sciences de la Nature et de la vie, Université Abbès Laghrour de Khenchela, 40000 Khenchela, Algeria, Tel: 213 540433804. E-mail: bouffenara@yahoo.fr

Received: 29 January 2016

Revised: 06 July 2016;

Accepted: 14 July 2016;

Published Online: 28 September 2016 
(70-80\%), mostly sugars, and thus show a high energy content. Although highly fibrous, date-pits have been considered an alternative feedstuff that may be included up to $50-75 \%$ in diets for ruminants (Hossain et al., 2014). Along with their nutrient and energy content, date fruits and seeds are rich in some plant secondary compounds with recognized pharmacological properties and positive effects on the consumer (Al-Orf et al., 2012).

Waste dates are conventionally used as supplementary feed for livestock in southern Algeria (Boudechiche et al., 2008). Waste dates are a rich in carbohydrates, dietary fiber and minerals, with lower contents in lipids and protein (Sidhu, 2006). Easily digestible sugars (fructose and glucose) are the main carbohydrates in dates (Al-Farsi et al., 2005; Myhara et al., 1999). Because of their composition, waste dates are highly palatable and digestible feedstuffs (Al-Dobaid et al., 2009), and may be a valuable source of energy to be used as suitable supplements to low quality roughages. There are some reports on the chemical composition and nutritive value of dates, but the available data on the potential value of DPBP as feeds are rather limited (Dayang et al., 2014). Not only waste dates, but also pedicels and dry palm leaves are used as feedstuffs for ruminants. In particular, there is scarce information on the rate and extent of fermentation of these by-products in the rumen.

The in vitro methods for feed evaluation have numerous advantages over in vivo methods (López, 2005). They are less expensive, less time consuming and allow incubation to be maintained more precisely than in vivo. In addition, in vitro techniques utilize small amounts of test feeds making them applicable to screening feeds that are not available in sufficient quantity for in vivo experiments.

The objective of this study was to evaluate, in vitro, the ruminal fermentation and nutritive value of dry palm leaves, pedicels, date-pits and waste dates from three different varieties. Vetch-oat hay was used as a reference material.

\section{MATERIALS AND METHODS}

\section{Forage and roughage material}

Palm leaves, pedicels, date-pits (taken from DegletNour tree) and waste dates from three different varieties (Bouarus, Harchaya, Kentichi) were harvested by hand in Biskra, in the Saharan Atlas region of Algeria (34 51.01 ' $\mathrm{N}, 04^{\circ} 43.40$ ' E). Mature waste dates of uniform size, free of physical damage and injury from insects and fungal infection, were selected and used for all experiments. Between twenty and thirty specimens of each palm leaves, pedicels and date-pits were collected to obtain a representative aliquot biomass. Vetch-oat hay, used as a control reference, was collected from the ITELV (Technical Institute of Breeding, Ain Mlila, Algeria). Samples and the reference forage from the different specimens were pooled, oven-dried at $50{ }^{\circ} \mathrm{C}$ (Makkar, 2003), and subsequently ground to pass a $1 \mathrm{~mm}$ screen.

\section{Chemical analysis}

Dry matter (DM, method ID 934.01), ash (method ID 942.05) and crude protein (CP, method ID 954.01) contents were determined following the methods of AOAC (2006). Neutral and acid detergent fibre (NDF and ADF, respectively) and sulphuric acid detergent lignin (ADL) were determined with an ANKOM 220 fibre analyser as described by Mertens (2002), AOAC (2006; Official method 973.18) and Robertson and Van Soest (1981), respectively. All fibre fractions were expressed including residual ash. As ether extract was not analyzed in the present experiment, the non-fiber carbohydrate (NFC) content of feeds was calculated by subtraction of CP, NDF and ash from total DM (Sniffen et al., 1992). The fat content of DPBP is usually very low $(<1 \%)$ except for date pits in which fat may represent up to $12 \%$ (Sidhu, 2006).

Volatile fatty acids (VFA) in the medium after 24 hours of incubation were determined by gas chromatography in an Agilent 6890 apparatus (Agilent Technologies España S. L., Madrid, Spain) fitted with a capillary column (HP-FFAP Polyethylene Glycol TPA-Treated, $30 \mathrm{~m}$ x $530 \mu \mathrm{m}$ i.d.x $1 \mu \mathrm{m}$ film thickness).

\section{Animals and rumen fluid extraction for in vitro studies}

Rumen fluid was extracted from adult Rasa Aragonesa ewes (average weight $71.5 \pm 0.87 \mathrm{~kg}$ ) fitted with a permanent ruminal cannula (50 $\mathrm{mm}$ internal diameter). Animals were daily fed $600 \mathrm{~g}$ lucerne hay (167 g CP, $502 \mathrm{~g}$ NDF, $355 \mathrm{~g}$ $\mathrm{ADF}$ and $71 \mathrm{~g} \mathrm{ADL} \mathrm{kg}^{-1} \mathrm{DM}$ ) and $300 \mathrm{~g}$ barley straw (31 g CP, $733 \mathrm{~g} \mathrm{NDF}, 522 \mathrm{~g}$ ADF and $108 \mathrm{~g} \mathrm{ADL} \mathrm{kg}^{-1} \mathrm{DM}$ ), and had free access to water and mineral/vitamin block. Samples of rumen contents (ca. $300 \mathrm{~mL}$ from each sheep) were withdrawn prior to morning feeding, transferred into thermos flasks and taken immediately to the laboratory, where rumen fluid was strained through various layers of cheesecloth and kept at $39^{\circ} \mathrm{C}$ under a constant flow of $\mathrm{CO}_{2}$.

\section{In vitro gas production kinetics}

Gas production profiles were obtained using the technique described by Theodorou et al. (1994) slightly modified. Ground samples $(500 \mathrm{mg}$ ) were incubated in $50 \mathrm{~mL}$ of diluted rumen fluid $(10 \mathrm{~mL}$ mixed rumen fluid $+40 \mathrm{~mL}$ medium prepared under a $\mathrm{CO}_{2}$ constant flow) in $120 \mathrm{~mL}$ serum bottles. The composition of the incubation medium was that described by Theodorou et al. (1994). Incubations were performed using three different inocula (rumen fluid from three sheep used separately) with two bottles per 
rumen fluid inoculum (for a total of six observations -three replicates- per sample). Two runs were carried out and six bottles (three per run) containing only diluted rumen fluid were incubated as blanks and used to compensate for gas production in the absence of substrate. Once filled up, all bottles were closed with rubber stoppers, crimped with aluminium seals, shaken and placed in an incubator at $39^{\circ} \mathrm{C}$. Volume of gas produced was recorded at $3,6,9,12,16,21,26,31,36,48,72,96,120$ and $144 \mathrm{~h}$ after inoculation with an HD2124.2 manometer provided with a TP804 pressure gauge (DELTA OHM, Caselle di Selvazzano, Italy). Pressure readings were converted into volume by using a pre-established linear regression between pressure recorded in the same type of bottles and known inoculated gas volumes (Marinas et al., 2003). At the end of the incubation (after $144 \mathrm{~h}$ ), the contents of each serum bottle were filtered using sintered glass crucibles (coarse porosity no. 1 , pore size $100-160 \mu \mathrm{m}$ ) under vacuum. Then the residue was washed out with distilled water and oven-dried at $100^{\circ} \mathrm{C}$ for $48 \mathrm{~h}$ to estimate the potential DM disappearance (D144, $\left.\mathrm{g} \mathrm{g}^{-1} \mathrm{DM}\right)$.

\section{Calculations}

In order to estimate the fermentation kinetic parameters, gas production data were fitted using the exponential model proposed by France et al. (2000):

$G=A\left[1-\mathrm{e}^{-c(t-L)}\right]$ for $\mathrm{t} \geq \mathrm{L}$

where $G(\mathrm{~mL} / \mathrm{g})$ denotes the cumulative gas production at time $t ; A\left(\mathrm{~mL} \mathrm{~g}^{-1}\right)$ is the asymptotic gas production; $c\left(\mathrm{~h}^{-1}\right)$ is the fractional rate of substrate fermentation and $L(h)$ is the lag time. Volume of gas $\left(\mathrm{mL} \mathrm{g}^{-1} \mathrm{DM}\right)$ produced after $24 \mathrm{~h}$ of incubation (G24) was used as an index of digestibility and energy feed value, as suggested by Menke and Steingass (1988). According to France et al. (2000), the extent of degradation (effective degradability) in the rumen $\left(\mathrm{ED}, \mathrm{g} \mathrm{g}^{-1} \mathrm{DM}\right)$ for a given rate of passage $\left(k, \mathrm{~h}^{-1}\right)$ was estimated as:

$$
E D=\frac{c \times D 144}{c+k} \mathrm{e}^{-k L},
$$

where $D 144$ is the dry matter disappearance after 144 hours of incubation. To calculate ED, a rate of passage of $0.03 \mathrm{~h}^{-1}$ (characteristic of a sheep fed a forage diet at maintenance level) was used.

The energy value and digestibility of feedstuffs were calculated from the amount of gas produced at $24 \mathrm{~h}$ of incubation with supplementary analyses of crude protein and ash, as follows (Menke and Steingass, 1988).

$$
\begin{aligned}
\mathrm{ME}(\mathrm{MJ} / \mathrm{kg} \mathrm{DM})= & 2.2+0.136 \times \mathrm{G} 24+0.057 \times \\
& \mathrm{CP}+0.029 \times \mathrm{CP}^{2}
\end{aligned}
$$

$$
\begin{aligned}
\mathrm{OMD}(\%)= & 14.88+0.889 \times \mathrm{G} 24+0.45 \times \mathrm{CP}+0.0651 \\
& \times \mathrm{ASH}
\end{aligned}
$$

Where

ME is the metabolizable energy

G24 is $24 \mathrm{~h}$ net gas production ( $\mathrm{mL} / 200 \mathrm{mg} \mathrm{DM}$ )

$\mathrm{CP}$ is crude protein (\% of $\mathrm{DM})$

$\mathrm{OMD}$ is organic matter digestibility

$\mathrm{ASH}$ is ash (\% of DM).

\section{Statistical analysis}

One way analysis of variance (Steel and Torrie, 1997) was performed on gas production fermentation kinetics, metabolizable energy, organic matter digestibility and volatile fatty acids data, with DPBP as the only source of variation (fixed effect) and source of inoculum (random effect) as a blocking factor. Tukey's test was used for the multiple comparison of means $(p<0.05)$. Analysis of variance and correlation between different variables were performed using SAS software package (SAS Institute, 2008).

\section{RESULTS}

\section{Chemical composition}

The chemical composition of the DPBP is shown in Table 1. All DPBP had low CP contents $(<7 \%)$ which in waste dates ranged from $18 \mathrm{~g} \mathrm{~kg}^{-1} \mathrm{DM}$ in Kentichi to $40 \mathrm{~g} \mathrm{~kg}^{-1} \mathrm{DM}$ in Harchaya. Protein content was greater in date-pits $\left(53 \mathrm{~g} \mathrm{~kg}^{-1} \mathrm{DM}\right)$ and palm leaves $\left(64 \mathrm{~g} \mathrm{~kg}^{-1} \mathrm{DM}\right)$ than in waste dates.

The ADF:NDF ratio was higher in palm leaves (0.71) and pedicels (0.64) than in vetch-oat hay (0.57). This result indicates the high cellulose and/or lignin content of the two DPBP. Based on their chemical composition, palm leaves, pedicels and date-pits could be classified as highly fibrous feeds with relatively medium protein content.

Table 1: Chemical composition ( $\mathrm{g} \mathrm{kg}^{-1}$ dry matter) of various date palm by-products and of the vetch-oat hay

\begin{tabular}{lcccccccc}
\hline $\begin{array}{l}\text { Date palm } \\
\text { by-products }\end{array}$ & $\begin{array}{c}\text { DM } \\
\left(\mathbf{g ~ k g}^{-1} \mathbf{f e e d}\right)\end{array}$ & OM & CP & NDF ADF ADL NFC \\
\hline Leaves & 963 & 848 & 64.4 & 609 & 435 & 83.8 & 137 \\
Pedicels & 942 & 938 & 35.6 & 557 & 358 & 79.0 & 288 \\
Date-pits & 977 & 989 & 52.5 & 636 & 410 & 56.9 & 277 \\
Bouarus waste dates & 954 & 949 & 27.5 & 79 & 45 & 22.9 & 796 \\
$\begin{array}{l}\text { Harchaya waste } \\
\text { dates }\end{array}$ & 941 & 960 & 40.4 & 87 & 49 & 26.5 & 773 \\
Kentichi waste dates & 958 & 964 & 17.7 & 93 & 47 & 23.6 & 811 \\
Vetch-oat hay & 929 & 937 & 53.8 & 579 & 331 & 46.1 & 233 \\
\hline
\end{tabular}

DM: Dry matter; OM: Organic matter; CP: Crude protein; NDF: Neutral detergent fibre expressed with residual ash; ADF: Acid detergent fibre expressed with residual ash; ADL: Acid detergent lignin expressed with residual ash, NFC; Non-fiber carbohydrate 


\section{In vitro gas production kinetics}

Data of in vitro fermentation kinetics are shown in Table 2. The lowest values of gas production, D144 and ED were observed for palm leaves, date-pits and pedicels (being particularly low for date-pits), whereas waste dates had significantly higher values. Similar trends were observed for the in vitro fermentation kinetics estimated from the gas production curves.

Fig. 1 shows the cumulative gas production profiles of the seven different samples that were incubated in buffered rumen fluid. For waste dates, pedicels and vetch-oat hay fermentation started readily without lag time, whereas for

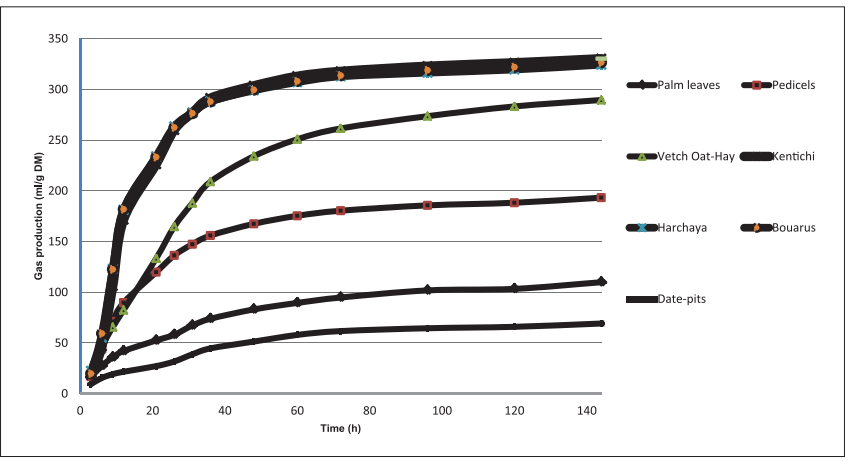

Fig 1. Cumulative gas production profiles for date palm by-products during in vitro incubation date pits and palm leaves there was some lag before any volume of fermentation gas could be measured.

The highest asymptotic gas production was observed in Kentichi, Harchaya and Bouarus dates (330, 327, $324 \mathrm{~mL} \mathrm{~g}^{-1} \mathrm{DM}$, respectively), whereas date-pits recorded the lowest value $\left(69 \mathrm{~mL} \mathrm{~g}^{-1} \mathrm{DM}\right)$.

\section{Energy content and organic matter digestibility}

The estimated metabolizable energy (ME), and organic matter digestibility (OMD) are presented in Table 2. The ME contents were particularly higher in all waste dates, while palm leaves and date-pits had significantly lower values of $\mathrm{ME}$ (5.43 and 4.12 $\mathrm{MJ} \mathrm{kg}^{-1} \mathrm{DM}$; respectively). The OMD also differed significantly among DPBP $(\mathrm{p}<0.001)$, being greater with waste dates and lower with date-pits. The OMD of pedicels was significantly higher than that of palm leaves, but lower than that of waste dates.

\section{Fermentation end-products}

There were differences $(\mathrm{p}<0.001)$ among DPBP in total and individual VFA concentration and acetate to propionate ratio after $24 \mathrm{~h}$ of incubation (Table 3 ). The lowest total VFA concentration was with date-pits $\left(21.1 \mathrm{mmol} \mathrm{L}^{-1}\right)$ and the highest with Bouarus waste dates $\left(42.7 \mathrm{mmol} \mathrm{L}^{-1}\right)$, whereas Kentichi waste dates showed an intermediate value (32.5 $\left.\mathrm{mmol} \mathrm{L}^{-1}\right)$. The concentration of acetate (major fatty

Table 2: In vitro fermentation kinetics (estimated from gas production curves) and predicted metabolizable energy (ME) content and organic matter digestibility (OMD) of date palm by-products and of the vetch-oat hay

\begin{tabular}{|c|c|c|c|c|c|c|c|}
\hline $\begin{array}{l}\text { Date palm } \\
\text { by-products }\end{array}$ & $A\left(m L g^{-1} D M\right)$ & $c\left(\mathrm{~h}^{-1}\right)$ & G24 (mL g-1 DM) & D144 (g g g $^{-1}$ ) & ED $\left(g g^{-1} D M\right)$ & ME (MJ kg-1DM) & OMD (\%) \\
\hline Leaves & $105 d$ & $0.035 c$ & $59.8 d$ & $0.311 d$ & $0.162 d$ & $5.43 e$ & $29.6 d$ \\
\hline Pedicels & $188 \mathrm{c}$ & $0.049 b$ & $130 c$ & $0.387 \mathrm{c}$ & $0.233 c$ & $6.55 d$ & $41.4 \mathrm{c}$ \\
\hline Date-pits & $69.9 \mathrm{e}$ & $0.028 d$ & $33.9 \mathrm{e}$ & $0.187 e$ & $0.087 e$ & $4.12 f$ & $22.7 e$ \\
\hline Bouarus waste dates & $324 a$ & $0.057 \mathrm{a}$ & $242 a$ & $0.776 a$ & $0.494 a$ & $9.67 b$ & $62.8 \mathrm{a}$ \\
\hline Harchaya waste dates & $322 a$ & $0.058 a$ & $242 a$ & $0.762 a$ & $0.487 a$ & $9.96 a$ & $63.1 \mathrm{a}$ \\
\hline Kentichi waste dates & $331 a$ & $0.052 b$ & $236 a$ & $0.786 a$ & $0.484 a$ & $9.55 b$ & $62.7 a$ \\
\hline Vetch-oat hay & $293 b$ & $0.032 \mathrm{~cd}$ & $155 b$ & $0.596 b$ & $0.296 b$ & $7.79 c$ & $46.7 b$ \\
\hline S.E.M. & 9.96 & 0.0038 & 8.48 & 0.0225 & 0.01294 & 0.181 & 1.20 \\
\hline
\end{tabular}

A: Asymptotic gas production, $c$ : Fractional rate of fermentation; G24: Gas production at 24 h of incubation; D144: DM disappearance after 144 h of incubation;

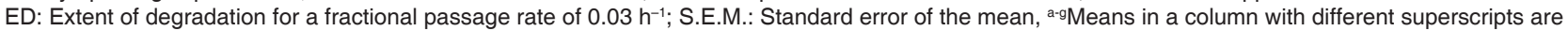
significantly different $(\mathrm{P}<0.05)$

Table 3: Total $\left(\mathrm{mmol} \mathrm{L}^{-1}\right)$ production of volatile fatty acids, molar proportions (\%), and acetate to propionate ratio (A:P) after $24 \mathrm{~h}$ of in vitro incubation of date palm by-products

\begin{tabular}{lcccccccc}
\hline $\begin{array}{l}\text { Date palm } \\
\text { by-products }\end{array}$ & Total & Acetate & Propionate & Isobutyrate & Butyrate & Isovalerate & Valerate & A:P \\
\hline Leaves & $21.9 \mathrm{e}$ & $63.7 \mathrm{a}$ & $23.3 \mathrm{c}$ & $0.79 \mathrm{ab}$ & $9.23 \mathrm{a}$ & $0.77 \mathrm{ab}$ & $2.25 \mathrm{a}$ & $2.78 \mathrm{a}$ \\
Pedicels & $30.0 \mathrm{c}$ & $58.4 \mathrm{a}$ & $28.5 \mathrm{~b}$ & $0.64 \mathrm{bc}$ & $10.36 \mathrm{ab}$ & $0.59 \mathrm{bc}$ & $1.54 \mathrm{bc}$ & $2.05 \mathrm{~b}$ \\
Date-pits & $21.1 \mathrm{e}$ & $66.1 \mathrm{a}$ & $22.0 \mathrm{c}$ & $0.84 \mathrm{a}$ & $7.83 \mathrm{bc}$ & $0.84 \mathrm{a}$ & $2.44 \mathrm{a}$ & $3.07 \mathrm{a}$ \\
Bouarus & $42.7 \mathrm{a}$ & $58.9 \mathrm{a}$ & $32.4 \mathrm{ab}$ & $0.38 \mathrm{~d}$ & $7.02 \mathrm{c}$ & $0.34 \mathrm{~d}$ & $1.03 \mathrm{~d}$ & $1.83 \mathrm{bc}$ \\
Harchaya & $26.0 \mathrm{~d}$ & $58.6 \mathrm{a}$ & $30.6 \mathrm{~b}$ & $0.71 \mathrm{abc}$ & $7.57 \mathrm{bc}$ & $0.83 \mathrm{a}$ & $1.74 \mathrm{~b}$ & $1.95 \mathrm{~b}$ \\
Kentichi & $32.5 \mathrm{c}$ & $48.0 \mathrm{~b}$ & $36.5 \mathrm{a}$ & $0.67 \mathrm{abc}$ & $12.99 \mathrm{a}$ & $0.46 \mathrm{~cd}$ & $1.47 \mathrm{bc}$ & $1.33 \mathrm{c}$ \\
Vetch-oat Hay & $36.2 \mathrm{~b}$ & $65.0 \mathrm{a}$ & $34.0 \mathrm{ab}$ & $0.58 \mathrm{c}$ & $7.68 \mathrm{bc}$ & $0.49 \mathrm{~cd}$ & $1.34 \mathrm{~cd}$ & $1.93 \mathrm{~b}$ \\
S.E.M. & 2.02 & 5.88 & 3.50 & 0.119 & 1.861 & 0.154 & 0.242 & 0.347 \\
\hline
\end{tabular}

a-gMeans in a column with different superscripts are significantly different $(<0.05)$, S.E.M.: Standard error of the mean. Bouarus, Harchaya and Kentichi, refer to waste dates of these varieties 
acid) differentiated two groups: Bouarus $\left(25.1 \mathrm{mmol} \mathrm{L}^{-1}\right)$, while the fermentation of palm leaves resulted in a lower acetate concentration $\left(13.9 \mathrm{mmol} \mathrm{L}^{-1}\right)$. The same tendency is shown for the concentrations of propionate that are higher in Bouarus and Kentichi dates and lower in palm leaves and date-pits. Pedicels showed intermediate values of acetate and propionate concentrations (17.6 and $8.6 \mathrm{mmol} \mathrm{L}^{-1}$; respectively).

Waste dates produced the highest molar proportions of butyrate and isobutyrate, whereas the acetate/propionate ratios were significantly different between treatments $(p<0.001)$. Acetate to propionate ratios ranged from 1.33 in Kentichi waste dates to 3.1 in date-pits.

\section{Relationships between chemical composition, and gas production and fermentation products}

The CP, NDF, ADF and ADL contents of the feedstuff were negatively correlated $(p<0.05)$ with 9,21 and $36 \mathrm{~h}$ gas production, and with G24 (Table 4). In addition, the fiber fractions were negatively correlated $(p<0.01)$ with D144. On the contrary, the NFC content was positively correlated with gas production at 21, 31 and $144 \mathrm{~h}$, and also with D144 $(\mathrm{p}<0.05)$ and G24 $(\mathrm{p}<0.01)$.

Extent of degradation (ED) was strongly and positively correlated with $A(\mathrm{r}=0.95, \mathrm{p}=0.001)$ and $c(\mathrm{r}=0.95$, $\mathrm{p}=0.014)$, whereas D144 was also positively correlated with $A(\mathrm{r}=0.98, \mathrm{p}<0.001)$ and $c(\mathrm{r}=0.77, \mathrm{p}=0.042)$.

Cell wall fractions (NDF and ADL) were negatively correlated with asymptotic gas production $(A)$ and fractional rate of gas production $(c)$.

The NDF $(\mathrm{p}<0.01)$, ADF $(\mathrm{p}<0.01)$ and ADL $(\mathrm{p}<0.05)$ were negatively correlated with ME and OMD (Table 4), whereas the NFC fraction was positively correlated with ME $(\mathrm{p}<0.05)$, and with OMD $(\mathrm{p}<0.01)$.

Positive correlations (Table 5) occurred between CP and $\mathrm{ADF}$ contents of the DPBP and the acetate to propionate ratio $(\mathrm{p}<0.05)$, and also between $24 \mathrm{~h}$ gas production and acetate concentration $(p<0.05)$. Propionate was correlated with ME and OMD $(\mathrm{p}<0.05)$. Positive correlations $(p<0.05)$ were observed between propionate concentration and D144 $(\mathrm{r}=0.82)$ or ED $(\mathrm{r}=0.78)$ of DPBP.

\section{DISCUSSION}

The DPBP studied herein are commonly used as feedstuffs for small ruminants farmed in Mediterranean rangelands (Kababya et al., 1998). Dates are used as fresh fruits for human consumption, and date by-products are used to

Table 4: Correlation coefficients between chemical composition parameters $\left(\mathrm{g} \mathrm{kg}^{-1} \mathrm{DM}\right)$, volume of in vitro gas production, gas production kinetics parameters, and predicted metabolizable energy (ME; MJ kg-1 DM) and organic matter digestibility (OMD), obtained for date palm by-products

\begin{tabular}{|c|c|c|c|c|c|c|c|c|c|c|c|}
\hline & \multicolumn{4}{|c|}{ Gas production ( $\left.\mathrm{mL} \mathrm{g}^{-1} \mathrm{DM}\right)$} & \multicolumn{5}{|c|}{ Gas production constants } & \multicolumn{2}{|c|}{ Energy value } \\
\hline & $9 \mathrm{~h}$ & $21 \mathrm{~h}$ & $36 \mathrm{~h}$ & $144 \mathrm{~h}$ & A & $c\left(\mathrm{~h}^{-1}\right)$ & ED & D144 & G24 & ME & OMD (\%) \\
\hline $\mathrm{CP}$ & $-0.75^{\star}$ & $-0.78^{\star}$ & $-0.76^{\star}$ & 0.69 & -0.68 & $-0.78^{*}$ & $-0.75^{\star}$ & -0.69 & $-0.77^{*}$ & -0.70 & $-0.76^{*}$ \\
\hline NDF & $-0.93^{\star *}$ & $-0.94^{\star *}$ & $-0.89^{* *}$ & $-0.82^{*}$ & $-0.82^{*}$ & $-0.88^{* *}$ & $-0.95^{\star *}$ & $-0.89^{* *}$ & -0.77 & $-0.91^{* *}$ & $-0.92^{* *}$ \\
\hline ADF & $-0.95^{\star *}$ & $-0.96^{\star *}$ & $-0.93^{\star *}$ & $-0.87^{*}$ & $-0.87^{*}$ & $-0.86^{\star}$ & $-0.97^{\star \star \star}$ & $-0.93^{\star *}$ & $-0.95^{\star \star}$ & $-0.94^{\star *}$ & $-0.93^{\star *}$ \\
\hline$A D L$ & $-0.78^{*}$ & $-0.83^{*}$ & $-0.84^{*}$ & $-0.81^{*}$ & $-0.82^{*}$ & -0.57 & $-0.85^{\star}$ & $-0.86^{* *}$ & $-0.83^{* *}$ & $-0.82^{*}$ & $-0.83^{*}$ \\
\hline NFC & $0.89^{* *}$ & $0.91^{\star *}$ & $0.86^{*}$ & $0.78^{*}$ & $0.78^{*}$ & $0.85^{\star}$ & $0.92^{* *}$ & $0.86^{\star *}$ & $0.89^{\star *}$ & $0.86^{*}$ & $0.88^{\star \star}$ \\
\hline
\end{tabular}

A: Asymptotic gas production ( $\left.\mathrm{mL} \mathrm{g}^{-1} \mathrm{DM}\right)$; ED: Extent of degradation for a fractional passage rate of $0.03 \mathrm{~h}^{-1}$; D144: DM disappearance after 144 $\mathrm{h}$ of incubation ( $\left.\mathrm{g} \mathrm{g}^{-1} \mathrm{DM}\right)$; G24: Gas production at $24 \mathrm{~h}$ of incubation ( $\left.\mathrm{mL} \mathrm{g}^{-1} \mathrm{DM}\right)$; CP: Crude protein; NDF: Neutral detergent fiber; ADF: Acid detergent fiber; ADL: Acid detergent lignin; c: Fractional rate of gas production $\left(\mathrm{h}^{-1}\right)$; NFC: Non-fiber carbohydrates. $* \mathrm{P}<0.05, * * \mathrm{P}<0.01, * * * \mathrm{P}<0.001$

Table 5: Correlation coefficients between volatile fatty acids $\left(\mathrm{mmol} \mathrm{L}^{-1}\right)$ production, chemical composition ( $\left.\mathrm{g} \mathrm{kg}^{-1} \mathrm{DM}\right)$, in vitro gas production kinetics parameters, and predicted metabolizable energy (ME; MJ kg-1DM) and organic matter digestibility (OMD), obtained for date palm by-products

\begin{tabular}{|c|c|c|c|c|c|c|c|c|c|c|c|c|}
\hline & \multirow[t]{2}{*}{ DM } & \multicolumn{4}{|c|}{ Chemical composition } & \multicolumn{5}{|c|}{ Gas production kinetics parameters } & \multicolumn{2}{|c|}{ Predicted ME and OMD } \\
\hline & & $\mathrm{CP}$ & NDF & ADF & ADL & A & $c\left(\mathrm{~h}^{-1}\right)$ & ED & D144 & G24 & ME & OMD (\%) \\
\hline Total & -0.49 & -0.58 & -0.49 & -0.55 & -0.56 & $0.75^{\star}$ & -0.46 & 0.65 & 0.69 & 0.48 & 0.67 & 0.68 \\
\hline Acetate & -0.47 & -0.31 & -0.29 & -0.35 & -0.39 & 0.55 & 0.29 & 0.45 & 0.49 & $0.81^{*}$ & 0.47 & 0.47 \\
\hline Propionate & -0.49 & -0.71 & -0.64 & -0.69 & -0.68 & $0.86^{*}$ & 0.56 & $0.78^{*}$ & $0.82^{*}$ & 0.22 & $0.79^{*}$ & $0.81^{*}$ \\
\hline Isobutyrate & -0.13 & -0.45 & -0.13 & -0.18 & -0.19 & 0.28 & 0.04 & 0.18 & 0.22 & 0.58 & 0.19 & 0.22 \\
\hline Butyrate & -0.20 & $-0.82^{*}$ & -0.48 & -0.50 & -0.37 & 0.59 & 0.49 & 0.56 & 0.57 & -0.10 & 0.54 & 0.59 \\
\hline Isovalerate & -0.14 & 0.30 & 0.06 & 0.07 & 0.14 & -0.17 & 0.07 & -0.18 & -0.17 & -0.75 & -0.09 & -0.11 \\
\hline Valerate & $0.82^{*}$ & 0.37 & 0.50 & 0.55 & 0.44 & $-0.78^{*}$ & -0.63 & -0.69 & -0.72 & $-0.89^{* *}$ & $-0.76^{*}$ & -0.74 \\
\hline$A: P$ & 0.57 & $0.80^{*}$ & 0.73 & $0.78^{*}$ & 0.66 & $-0.92^{\star \star}$ & -0.71 & $-0.87^{*}$ & $-0.89^{\star *}$ & 0.69 & $-0.88^{\star *}$ & $-0.90^{*}$ \\
\hline
\end{tabular}

DM: Dry matter; CP: Crude protein; NDF: Neutral detergent fiber; ADF: Acid detergent fiber; ADL: Acid detergent lignin; A: Asymptotic gas production $\left(\mathrm{mL} \mathrm{g}^{-1} \mathrm{DM}\right)$; c: Fractional rate of gas production $\left(\mathrm{h}^{-1}\right)$; ED: Extent of degradation for a fractional passage rate of $0.03 \mathrm{~h}^{-1}$; $\mathrm{D} 144$ : DM disappearance after $144 \mathrm{~h}$ of incubation ( $\left.\mathrm{g} \mathrm{g}^{-1} \mathrm{DM}\right)$; G24: Gas production at $24 \mathrm{~h}$ of incubation $\left(\mathrm{mL} \mathrm{g}^{-1} \mathrm{DM}\right)$; A: $\mathrm{P}$. Acetate to propionate ratio. ${ }^{*} \mathrm{P}<0.05,{ }^{\star \star} \mathrm{P}<0.01,{ }^{\star \star \star} \mathrm{P}<0.001$. 
produce juice, syrup, jam, jelly or fermented beverage (Chandrasekaran and Bahkali, 2013). Discarded fruits (waste dates) from sorting, grading, storage or processing are often used as animal feed (El-Hadrami, 2012). These by-products are available when fodder yield from pastures is decreased, and may represent a interesting supplement to the herbaceous vegetation (Delillis and Fontanella, 1992). DPBP are more important when the availability of grass declines.

The value of DPBP as feeds is limited by their low CP content (Wilson, 1977). The protein content in pits from seven Saudi date varieties ranged from 4.8 to $7.5 \%$ (AlShowiman, 1990). Mature date fruits usually contain less than 3\% protein (Al-Orf et al., 2012). The CP contents of DPBP found in the present work for waste dates were in agreement with those reported by Longuo et al. (1989), Chehma and Longuo (2004) and Genin et al. (2004) who reported a low nitrogen content $(4.5 \%)$ for waste dates of deglet noor variety. The CP content of DPBP was thus below the level required (70-80 $\mathrm{g} \mathrm{CP} / \mathrm{kg}$ DM) for optimum rumen function (Van Soest, 1994; Boufennara et al., 2012). Norton et al. (1994) concluded that such a low dietary N supply is not sufficient to ensure an optimal metabolic activity and growth of ruminal microbiota.

The cell wall (NDF, ADF and lignin) contents of waste dates are in agreement with el-Shazly et al. (1963) and Al-Ani et al. (1991) but not with Genin et al. (2004) and Al-Farsi et al. (2007). Chemical composition of palm leaves was similar to that reported by Pascual et al. (2000), but the NDF was lower than that mentioned by Genin et al. (2004). Such inconsistency in the chemical composition of DPBP may be due to the type and origin of the parent date fruit and the extraction technique used in date palm processing. Other factors (soil characteristics, date palm tree variety or age) may cause variations in the chemical composition of date fruits. The contents of NDF, ADF and CP in date-pits were similar to the results obtained by Genin et al. (2004). Date pits are the only DPBP relatively rich in fat (5-12\%), and are very rich in dietary fibre (Hossain et al., 2014). The high level of fibre content in palm leaves, pedicels and date-pits could be related in part to the climatic and local conditions prevailing in the area. Cell wall content in plants and fruits is normally increased under hotter and drier conditions (Pascual et al., 2000). Concerning the vetch-oat hay used as reference, its chemical composition was similar to that reported by Hadjigeorgiou et al. (2003) for a range of grass hays.

The use of the in vitro gas production methodology to estimate digestion of feeds is based on the well established relationship between the feed digestibility and in vitro gas production, in combination with the feed chemical composition (Menke and Steingass, 1988; López, 2005). The in vitro gas production system aids to better assess nutrient utilization, and its accuracy in describing digestibility in animals has been extensively validated (López, 2005). Since the utilization of roughages is largely dependent upon microbial fermentation within the rumen, description of roughages in terms of their degradation characteristics would provide a useful basis for their evaluation.

In the current experiment, the highest cumulative gas production after 144 hours of incubation was observed for Kentichi waste dates $\left(330 \mathrm{~mL} \mathrm{~g}^{-1} \mathrm{DM}\right)$ and the lowest was obtained with date-pits $\left(69 \mathrm{~mL} \mathrm{~g}^{-1} \mathrm{DM}\right)$. The high cell wall and lignin contents in date-pits could have accounted for the limited substrate degradation and fermentation, and consequently for the low gas production observed.

The profile of fermentation of the substrates is a characteristic of the fibrous substrates which determine both the rates of degradation and passage in the rumen. Therefore, in order to maximize the nutrient supply from palm leaves, long residence times in the rumen may be required which may allow the rumen microbes to attach and degrade the fiber that may otherwise be resistant to microbial enzymes (Salawu et al., 1999).

Gas production from waste dates was clearly higher than that from conventional forages, such as mountain herbage (Andrighetto et al., 1992), pasture hay (Gulsen et al., 2004), or alfalfa hay (Lantcheva et al., 1999). These results suggest that these waste dates can be used as feeds for ruminants. Waste dates are rich in soluble sugars, vitamins and minerals, and consequently have been used as fermentation substrate for the production of antibiotics (Sidhu, 2006) or other biotechnological processes based on microbial fermentation (Chandrasekaran and Bahkali, 2013). Our results suggest that these waste dates would be also a highly fermentable feedstuff in the rumen that could represent a substantial supply of energy to the animal. Adequately combined with a source of degradable $\mathrm{N}$, it can favor the synthesis of microbial protein in the rumen. Vetch-oat hay is very fermentable due to the association of a legume (Vicia sativa) and a grass (Avena sativa), which provides degradable nitrogen and fermentable organic matter for an adequate microbial synthesis (Getachew et al., 2004).

The extent of degradation (ED) of DPBP ranged between $0.494 \mathrm{~g} \mathrm{~g}^{-1} \mathrm{DM}$ for Bouarus waste dates and $0.087 \mathrm{~g} \mathrm{~g}^{-1} \mathrm{DM}$ for date-pits. The high values obtained with waste dates could be explained by the low levels of cell wall fractions NDF, ADF and ADL.

Dry matter disappearance after 144 h of incubation (D144) differentiates two groups. Leaves, pedicels and date-pits 
had low values $(<39 \%)$, whereas waste dates showed a higher potential rumen degradation $(>70 \%)$, confirming the high energetic value of these by-products. These results are consistent with lower fibre contents of waste dates in comparison with date-pits, palm leaves and pedicels. Generally, as cell wall (fibre) increases, digestibility and energy content decrease (Van Soest, 1994). Our results were in line with those reported by Mahgoub et al. (2005), Genin et al. (2004) and Dayani et al. (2012), who observed higher digestibility of date pulp with lower cell-wall content.

The low in vitro DM digestibility of date palm leaves was in agreement with other published studies (Longuo et al., 1989; Genin et al., 2004; Arhab et al., 2006). Date pits showed significant lower values of D144 than those found by Gihad et al. (1989) in sheep. Highly fibrous DPBP could be treated with chemicals $(\mathrm{NaOH})$ or fibrolytic enzymes to enhance their digestibility (Sidhu, 2006).

The CP content of DPBP was negatively correlated to gas production at $9 \mathrm{~h}$ and $36 \mathrm{~h}$, in agreement with data reported by Getachew et al., (2004) for feedstuffs collected from commercial dairy farms. On the other hand, Larbi et al., (1998) noted that the CP content of some shrubs was positively correlated with potential gas production.

Cell wall components (NDF, ADF and ADL) were negatively correlated with gas production at all incubation times, maybe as a result of a reduced microbial activity on highly lignified fibrous substrates. The negative correlation between cell wall content (NDF and ADF) and volume of gas production at all incubation times is consistent with other studies (Larbi et al., 1998) and the negative effect of NDF and $\mathrm{ADF}$ on digestibility is in close agreement with Lantcheva et al. (1999). This demonstrates that the effect of NDF and ADF on fermentation becomes less important as the level of NDF and ADF declines. Date by-products may also contain phenolic acids and condensed tannins (Sidhu, 2006). These secondary compounds could limit ruminal degradation of some of the DPBP, but most likely not that of waste dates, which are highly fermentable.

Menke and Steingass (1988) derived equations to predict OM digestibility and ME content of feed from in vitro gas production and chemical composition. The ME values of DPBP predicted using these equations were in agreement with those reported by Genin et al. (2004) who mentioned higher in vitro digestibility of waste dates with respect to other DPBP.

When feedstuffs are incubated in vitro, gas is produced mainly from the fermentation of carbohydrates (Blummel and Orskov, 1993), with a small contribution from the fermentation of protein or fat (Wolin, 1960). Al-Farsi and
Lee (2008) and Sharifi et al. (2015) reported that date fruit consists of $70-88 \%$ carbohydrates, most of which is in the form of sugars, mainly glucose, sucrose and fructose. Consequently, date fruits are considered a concentrate source of energy. The variation in the in vitro gas production of DPBP was directly related to differences in other fermentation end-products (total VFA production).

A high acetate to propionate ratio is an indication of a more acetogenic fermentation, associated to the activity of fibrolytic bacteria degrading substrates rich in structural carbohydrates (Getachew et al., 2004; Blummel et al., 1999). This was evident in the current experiment from the higher acetate to propionate ratio in date-pits and palm leaves. Similar ratios have also been obtained from other substrates rich in NDF (Getachew et al., 2004). Acetate to propionate ratios of 3.0-4.1 were reported in vivo (DePeters et al., 1997) and of 2.0-4.1 in vitro (Blummel et al., 1999) for different feedstuffs. With waste dates (less NDF content) the acetate to propionate ratio was decreased, reflecting an increased higher propionate production from the fermentation of non-fibre carbohydrates. According to McDonald et al. (2011), the fermentation of food rich in starch tends to produce more of propionate, whereas the fermentation of fibrous substrate yields more acetate. Acetic and butyric fermentations result in a greater production of gas, whereas the fermentation to propionate only releases gas when the acid is buffered. Thus feeds that produce high amounts of propionate yield relative less fermentation gas per unit of fermented substrate (Beuvink and Spoelstra, 1992).

\section{CONCLUSIONS}

The results obtained in the present work allows clustering the studied DPBP in two groups: one including the highly fibrous poor-quality ones (palm leaves and date-pits) and another one including the highly digestible waste dates. However, protein supplementation will be required when waste dates and the other date by-products are included in the diet for ruminants. Palm leaves and date-pits, with high fibre and limited CP content can be considered as roughage bulky feedstuffs for range ruminants when grazing herbaceous material becomes insufficient. Nevertheless, in vivo feeding trials would be needed to validate this conclusion.

\section{ACKNOWLEDGMENTS}

Financial support received from the Algerian Ministry of Higher Education and Scientific is gratefully acknowledged. The author is grateful to the Animal Nutrition laboratory, Facultad de Veterinaria, Zaragoza, Spain, for accepting performing all experiments in there. The author also is 
grateful to J. Artajona for his assistance and technical support.

\section{Authors contribution}

S. B. made a major contribution to the paper and conducted most of the experiments, analyzed the results and was responsible for the manuscript writing. L. B. have contributed in chemical analysis. Z. A. assisted in collecting rumen fluid from sheep and helping in recording volume of gas produced at several incubation times. A. de V. and M. F. were responsible for planning, designing the whole experiments and revising the manuscript. S. L. made a major contribution in consultant assistance, data analysis, presentation and manuscript preparation.

\section{Abbreviations used}

A, asymptotic gas production; A:P, acetate to propionate ratio; $\mathrm{ADF}$, acid detergent fibre expressed with residual ash; ADL, acid detergent lignin; $c$, fractional rate of gas production; CP, crude protein; DM, dry matter; DPBP, date palm by-products; D144, dry matter disappearance after 144 h of incubation; ED, effective degradability; G24, cumulative gas production at $24 \mathrm{~h}$; ME, Metabolizable energy; NFC, non-fiber carbohydrate; NDF, neutral detergent fibre expressed with residual ash; OM, organic matter; OMD, organic matter digestibility; VFA, volatile fatty acids.

\section{REFERENCES}

Al-Ani, A. N., S. A. Hassan and R. A. Al-Jassim. 1991. Dried date pulp in fattening diets for Awassi lambs. Small Rumin. Res. 6: 31-37.

Al-Dobaid, S. N., M. A. Mehaia and M. H. Khalil. 2009. Effect of feeding discarded dates on milk yield and composition of Aradi goats. Small Rumin. Res. 81: 167-170.

Al-Farsi, M. A. and C. Y. Lee. 2008. Nutritional and functional properties of dates: A review. Crit. Rev. Food Sci. Nutr. 48: 877-887.

Al-Farsi, M., C. Alasalvar, A. Morris, M. Baron and F. Shahidi. 2005. Compositional and sensory characteristics of three native sundried date (Phoenix dactylifera L.) varieties grown in Oman. J. Agric. Food Chem. 53: 7586-7591.

Al-Farsi, M., C. Alasalvar, M. Al-Abid, K. Al-Shoaily, M. Al-Amry and F. Al-Rawahy. 2007. Compositional and functional characteristics of dates, syrups, and their by-products. Food Chem. 104: 943-947.

Al-Orf, S. M., M. H. M. Ahmed, N. Al-Atwai, H. Al-Zaidi, A. Dehwah and S. Dehwah. 2012. Review: Nutritional properties and benefits of the date fruits (Phoenix dactylifera L.). Bull. Natl. Nutr. Inst. Arab. Rep. Egypt. 39: 97-129.

Al-Showiman, S. S. 1990. Chemical composition of date palm seeds (Phoenix dactylifera L.) in Saudi Arabia. Arab. Gulf. J. Sci. Res. 8: 15-24.

Andrighetto, I., L. Grubber, G. Cozzi, G. Uray, G. Giidetti and K. Buchgraber. 1992. Prediction of digestible organic matter and in vivo dry matter from the chemical composition, in vitro and in situ measurements on native mountain forages. Anim. Feed
Sci. Technol. 39: 323-333.

AOAC, Association of Official Analytical Chemists International. 2006. Official Methods of Analysis, $18^{\text {th }}$ ed. Current through Revision 1. AOAC, Gaithersburg, MD.

Arhab, R., D. Macheboeuf, M. Doreau and H. Bousseboua. 2006. Nutritive value of date palm leaves and Aristida pungens estimated by chemical, in vitro and in situ methods. Trop. Subtrop. Agroecosys. 6: 167-175.

Beuvink, J. M. W. and S. F. Spoelstra. 1992. Interactions between substrate, fermentation end-products, buffering systems and gas production upon fermentation of different carbohydrates by mixed rumen microorganisms in vitro. Appl. Microbiol. Biotechnol. 37: 505-509.

Blummel, M. and E. R. Orskov. 1993. Comparison of gas production and nylon bag degradability of roughages in predicting feed intake in cattle. Anim. Feed Sci. Technol. 40: 109-119.

Blummel, M., K. P. Aiple, H. Steingass and K. Becker. 1999. A note on the stoichiometrical relationship of short chain fatty acids production and gas evolution in vitro in feedstuffs of widely differing quality. J. Anim. Physiol. Anim. Nutr. 81: 157-167.

Boudechiche, L., A. Araba and R. Ouzrout. 2008. Influence du type de complément énergétique (rebuts de dattes vs orge) sur les performances d'engraissement et caractéristiques des carcasses d'agneaux Berbères à l'engraissement. Rev. Élev. Méd. Vét. Pays Trop. 61: 209-214.

Boufennara, S., S. Lopez, H. Bousseboua, R. Bodas and L. Bouazza. 2012. Chemical composition and digestibility of some browse species collected from Algerian arid Rangelands. Spanish J. Agric. Res. 10: 88-98.

Chandrasekaran, M. and A. H. Bahkali. 2013. Valorization of date palm (Phoenix dactylifera) fruit processing by-products and wastes using bioprocess technology - Review. Saudi J. Biol. Sci. 20: 105-120.

Chehma, A. and H. F. Longuo. 2004. Bilan azoté et gain de poids chez le dromadaire et le mouton, alimentés à base de sousproduits du palmier dattier, de la paille d'orge du Drin. Cahiers Agric. 13: 221-226.

Dayang, J. F., C. R. Reuben and F. Raji. 2014. Nutritional, socioeconomic and health benefits of dates. Int. J. Food Nutr. Sci. 3: 63-73.

Dayani, O., A. Khezri and A. G. Moradi. 2012. Determination of nutritive value of date palm by-products using in vitro and in situ measurements. Small Rumin. Res. 105: 122-125.

Delillis, M. and A. Fontanella. 1992. Comparative and growth in different species of the Mediterranean Maquis of central Italy. Vegetation. 100: 83-96.

DePeters, E. J., J. G. Fadel and A. Arosemena. 1997. Digestion kinetics of neutral detergent fiber and chemical composition within some selected by-product feedstuffs. Anim. Feed Sci. Technol. 67: 127-140.

El-Hadrami, A. and J. M. Al-Khayri. 2012. Socioeconomic and traditional importance of date palm. Emirates J. Food Agric. 24: 371-385.

El Hag, M. G. 1995. Production of animal feeds from dates and date by-products in the Sultanate. A review. Int. J. Anim. Sci. 10: 195-201.

el-Shazly, K., E. A. Ibrahim and H. A. Kara. 1963. Nutritional value of date seeds for sheep. J. Anim. Sci. 22: 894-897.

France, J., J. Dijkstra, M. S. Dhanoa, S. Lopez and A. Bannink. 2000. Estimating the extent of degradation of ruminant feeds from a description of their gas production profiles observed in vitro: Derivation of models and other mathematical considerations. $\mathrm{Br}$ 
J. Nutr. 83: 143-150.

Genin, D, A. Kadri, T. Khorchani, K. Sakkal, F. Belgacem and M. Hamadi. 2004. Valorisation of date-palm by-products (DPBP) for livestock feeding in Southern Tunisia. I - Potentialities and traditional utilisation. Options Méd. Sér. A. 59: 221-226.

Getachew, G., P. H. Robinson, E. J. DePeters and S. J. Taylor. 2004. Relationships between chemical composition, dry matter degradation and in vitro gas production of several ruminant feeds. Anim. Feed Sci. Technol. 111: 57-71.

Gihad, E. A., T. T. El Gallad, A. E. Souad, H. M Bou El-Nasr and M. F. A Arid. 1989. Feed and water intake, digestibility and nitrogen utilization by camels compared to sheep's and goats fed low protein desert by products. Options Méd. Sér. A. 2: 75-81.

Gulsen, N., B. Coskun, H. D. Umucahlar and H. Dural. 2004. Prediction of nutritive value of native forage, Prangos uechritzii, using of in situ and in vitro measurements. J. Arid Environ. 56: 167-179.

Hadjigeorgiou, I. E., I. J. Gordon and J. A. Milne. 2003. Comparative preference by sheep and goats for Graminaeae forages varying in chemical composition. Small Rumin. Res. 49: 147-156.

Hossain, M. Z., M. I. Waly, V. Singh, V. Sequeira and M. S. Rahman. 2014. Chemical composition of date-pits and its potential for developing value-added product - A review. Pol. J. Food Nutr. Sci. 64: 215-226.

Kababya, D., A. Perevolotsky, I. Bruckental and S. Landau. 1998. Selection of diets by dual-purpose Mamber goats in Mediterranean woodland. J. Agric. Sci. 131: 221-228.

Lantcheva, N., H. Steingass, N. Todorov and D. Pavlov. 1999. A comparison of in vitro rumen fluid and enzymatic methods to predict digestibility and energy value of grass and alfalfa hay. Anim. Feed Sci. Technol. 81: 333-344.

Larbi, A., J. W. Smith, I. O. Kurdi, I. O. Adekunle, A. M. Raji and D. O. Ladipo. 1998. Chemical composition, rumen degradation and gas production characteristics of some multipurpose fodder trees and shrubs during wet and dry seasons in the humid tropics. Anim. Feed Sci. Technol. 72: 81-96.

Longuo, H. F., A. Chehma and A. O. Belkher. 1989. Quelques aspects botaniques et nutritionnels des pâturages des dromadaires en Algérie. In: Séminaire sur la digestion, la nutrition et l'alimentation des dromadaires. Options Méd. Sér. A. 2: 47-53.

López, S. 2005. In vitro and in situ techniques for estimating digestibility. In: Dijkstra, J., J. M. Forbes and J. France (Eds.), Quantitative Aspects of Ruminant Digestion and Metabolism, $2^{\text {nd }}$ ed. CAB International, Wallinford, UK, pp. 87-121.

Mahgoub, O., I. T. Kadim, M. H. Al-Busaidi, K. Annamalai and N. M. Al-Saqri. 2007. Effects of feeding ensiled date palm fronds and a by-product concentrate on performance and meat quality of Omani sheep. Anim. Feed Sci. Technol. 135: 210-221.

Makkar, H. P. S. 2003. Quantification of Tannins in Tree and Shrub Foliage. A Laboratory Manual, Kluwer Academic Publishers, Dordrecht, The Netherlands.

Marinas, A., R. García-González and M. Fondevila. 2003. The nutritive value of five pasture species occurring in the summer grazing ranges of the Pyrenees. Anim. Sci. 76: 461-469.

McDonald, P., R. A. Edwards, J. F. Greenhalgh, C. A. Morgan, L. A. Sinclair and R. G. Wilkinson. 2011. Animal Nutrition, $7^{\text {th }}$ ed. Prentice Hall, Pearson, Harlow, UK. p. 692.
Menke, K. H. and H. Steingass. 1988. Estimation of the energetic feed value obtained from chemical analyses and gas production using rumen fluid. Anim. Res. Dev. 28: 7-55.

Mertens, D. R. 2002. Gravimetric determination of amylase-treated neutral detergent fiber in feeds with refluxing in beaker or crucibles: Collaborative study. J. AOAC. Int. 85: 1217-1240.

Myhara, R. H., J. Karkalas and M. S. Taylor, 1999. The composition of maturing Omani dates. J. Sci. Food Agric. 79: 1345-1350.

Norton, B. W. 1994. The nutritive value of tree legumes. In: Gutteridge, C. and H. Shelton (Eds.), Forage Tree Legumes in Tropical Agriculture, CAB International, Wallingford, UK, pp. 177-192.

Osman, M., T. K. Isam., H. J. Eugene, A. Srikandakumar, N. M. Al-Saqri, A. S. Al-Abri and A. Ritchie. 2005. The use of a concentrate containing Meskit (Prosopis juliflora) pods and date palm by-products to replace commercial concentrate in diets of Omani sheep. Anim. Feed Sci. Technol. 120: 33-41.

Pascual, J. J., C. Fernandez, J. R. Diaz, C. Garces and J. RubertAleman. 2000. Voluntary intake and in vivo digestibilty of different date-palm fractions by Murciano-Granadina (Capra Hirsus). J. Arid. Environ. 45: 183-189.

Robertson, J. B. and P. J. Van Soest. 1981. The detergent system of analysis. In: James, W. P. T. and O. Theander (Eds.), The Analysis of Dietary Fibre in Food, Marcel Dekker, New York, pp. 123-158.

SAS Institute INC. 2008. SAS/STAT® 9.2 User's Guide, SAS Institute Inc., Cary, NC, USA.

Salawu, M. B., T. Acamovic, C. S. Stewart, T. Hvelplund and M. R. Weisbjerg. 1999. The use of tannins as silage additives: Effect on silage composition and mobile bag disappearance of dry matter and protein. Anim. Feed Sci. Technol. 82: 243-259.

Sharifi, M., M. Bashtani, A. A. Naserian and H. Farhangfar. 2015. The effect of feeding low quality date palm (Phoenix dactylifera L.) on the performance, antioxidant status and ruminal fermentation of mid-lactating Saanen dairy goats. Small Rumin. Res. 130: 95-100.

Sidhu, J. S. 2006. Date fruits production and processing. In: Hui, Y. H (Ed.), Handbook of Fruits and Fruit Processing, Blackwell Publishing, Ames, lowa, USA, pp. 391-419.

Sniffen, C. J., J. D. O'Connor, P. J. Van Soest, D. G. Fox and J. B. Russell. 1992. A net carbohydrate and protein system for evaluating cattle diets. II. Carbohydrate and protein availability. J. Anim. Sci. 70: 3562-3577.

Steel, R. G. and J. H. Torrie. 1997. Principles and Procedures of Statistics. A Biometrical Approach, McGraw-Hill Co., New York, USA. p. 666.

Theodorou, M. K., B. A. Willams., M. S. Dhanoa, A. B. McAllan and J. France. 1994. A simple gas production method using a pressure transducer to determine the fermentation kinetics of ruminant feeds. Anim. Feed Sci. Technol. 48: 185-197.

Van Soest, P. J. 1994. Nutritional Ecology of the Ruminant, Cornell University Press, Ithaca, NY.

Wolin, M. J. 1960. A theoretical rumen fermentation balance. J. Dairy Sci. 43: 1452-1459.

Wilson, A. D. 1977. The digestibility and voluntary intake of the leaves of trees and shrubs by sheep and goats. Aust. J. Agric. Res. 28: 501-508. 